\author{
Research Article
}

\title{
A COMPARATIVE CLINICAL EVALUATION ON THE EFFICACY OF KUBERAKSHA \& YAVA WITH LIFESTYLE MODIFICATION, IN THE MANAGEMENT OF PRAMEHA WITH SPECIAL REFERENCE TO PREDIABETES
}

\section{Trisha Talapatra1*, Sukumar Ghosh ${ }^{2}$, Rina Ghosh ${ }^{3}$, Shailendra Kumar Singh4}

${ }^{* 1}$ P.G Scholar, ${ }^{2}$ Professor and HOD, Department of Kayachikitsa, ${ }^{3}$ Associate Professor, Department of Roga Nidan Evum Vikriti Vigyan, Institute of Post Graduate Ayurvedic Education \& Research at S.V.S.P, 294, 3/1, Kol-09, West Bengal, India.

${ }^{4}$ Senior Ayurvedic Medical Officer, SAD Kona, Jagacha New PHC, Howrah, West Bengal, India.

\begin{tabular}{|c|c|}
\hline Article info & ABSTRACT \\
\hline Article History: & We are living in the age of complexity, contradiction, and challenge relating to various health \\
\hline Received: 25-09-2021 & issues such as lifestyle disorder, ageing, mental health euthanasia, drug resistance and so on. \\
\hline Revised : 09-10-2021 & Diabetes Mellitus is a Giant disease and major health issue that has reached alarming level in \\
\hline Accepted: 29-10-2021 & spite of terrific advance in modern medical science. Prediabetes is the precursor stage before \\
\hline Published: 07-11-2021 & Diabetes Mellitus, in which not all of the symptoms required to diagnose diabetes are \\
\hline $\begin{array}{l}\text { KEYWORDS: } \\
\text { Prediabetes, } \\
\text { Kuberaksha, Yava, } \\
\text { Anushanga vyadhi. }\end{array}$ & $\begin{array}{l}\text { present, but blood sugar is abnormally high. Prediabetic persons are considered to be at } \\
\text { increased risk for the subsequent development Diabetes Mellitus. Sushruta Samhita } \\
\text { mentioned, all varieties of Prameha if not treated at appropriate time, become changed to } \\
\text { Madhumeha which is incurable. So, early detection, treatment and prevention of this disease } \\
\text { in Prediabetic stage is needed. The modification of lifestyle should be the first aim and } \\
\text { objectives to restrict or combat such problems, beside this prime objective, some medication } \\
\text { which is safe and efficacious to be introduced. So, a clinical study with } 60 \text { patients has been } \\
\text { conducted on Prediabetes through the management with 'Kuberaksha' and 'Yava' in such } 2 \\
\text { groups of treatment. The two drugs are carrying such properties which acts in Samprapti } \\
\text { vighatana (prevent pathogenesis) of the disease. In both cases statistically significant results } \\
\text { are found (P<0.001 \& <0.01). On comparison between two groups Kuberaksha powder } \\
\text { showed better result than Yava powder. }\end{array}$ \\
\hline
\end{tabular}

\section{INTRODUCTION}

In Ayurvedic compendium, the disease Prameha has been described with great importance. It has been mentioned under 'Astha Mahagada' (eight disease of great importance)[1]. It has also been mentioned as foremost 'Anushanga Vyadhi' (relapsing disease)[2]. In the recent reports it is stated that, Prameha in term of Diabetes is the eighth leading cause of death in worldwide in 2012 [3]. More than 422 million people are suffering from this disease throughout the world in $2014{ }^{[4]}$.

\begin{tabular}{|l|l|}
\hline \multicolumn{3}{|c|}{ Access this article online } \\
\hline Quick Response Code & \\
\hline &
\end{tabular}

The International Diabetes Federation has estimated the number of diabetes patient in India is 61.3 million (2011) which is projected to be 101.2 million on 2030 [5]. That's why WHO has declared in the year 2014 that 'India is the Diabetes Capital of The World' [6]. The main etiopathogenesis of Prameha in general addiction to the pleasure of sedentary habits, sleep, curds, soup of meat of domesticated and aquatic animal, milk preparations and like all others Kapha aggravating factors increases the watery parts (Drava guna) of Kapha which causes Agnimandya and produces ' $a m a$ ', this ama entered into the Shrotas as kledas and flows to Mutrvaha shrota as well as visit vasti for its 'Drava and Sarana' guna. Simultaneously other parts of 'ama' gets entry to the other Dhatus and dearranged the 'Dhatwagni paka', which leads to Bahubaddha meda and Mamsa dhatu in the system in general. In pathogenesis more or less each body elements is involved concluding the disease of vast systemic consideration. 
The US Department of Health and Human Services' and 'American Diabetes Association' on 27th march 2002 gave the term 'Pre-diabetes'. The term 'increased risk for Diabetes' (ADA) and 'intermediate Hyperglycaemia' (WHO) used rather than Prediabetes [7]. Pre-diabetes is a condition in which individuals have blood glucose level higher than normal but not high enough to be classified as diabetes. An estimated $34 \%$ of adults have pre-diabetes. If left untreated $37 \%$ of the individuals with pre-diabetes may have diabetes in 4 years. ${ }^{[8]}$. ADA criteria for diagnosis of Prediabetes are, FBS 100-125 mg/dl, PPBS 140-199 mg/dl and HbA1c 5.7-6.4 [9]

In Prameha there is predominance of 'Kapha' among Tridosha and 'Meda' among 10 Dushyas. 'Kuberaksha' having Tikta-kasaya rasa, Katu vipak and Tridosha hara property, its seed contains flavonoids, triterpenoids and steroid which act as an antioxidant and free radical scavengers and responsible for antidiabetic action, additionally its Ushna virya will be able to enhance agni by reducing the Kapha. On the other hand, 'Yava' having properties like Kapha-pitta prasamana, Lekhana, Medohara, and Dhatwagni bardhak. In Prameha the Dhatwagni paka, specifically the activity of Medagni gets destroyed, which are very much essential for generation of Agni. It reduces the Apa and Prithvi Mahabhuta which are the main components of Meda dhatu, so in analogous action they diminish Meda dhatu and clear the Channels, and further transportation to deeper Dhatus occurs.

Modern hypoglycemic drugs are useful in the treatment of diabetes but restricted by the

\section{Sample Design}

\begin{tabular}{|l|l|}
\hline Group A & $\begin{array}{l}\text { 30 patients were included in this group with oral } \\
\text { drug under coverage of prescribed Pathya and } \\
\text { Apathya. Treated with Kuberaksha seed powder } \\
\text { 2 gm BD, Before lunch, twice daily with water } \\
\text { for 3 months. }\end{array}$ \\
\hline Group B & $\begin{array}{l}\text { 30 patients were included in this group with oral } \\
\text { drug under coverage of prescribed Pathya and } \\
\text { Apathya. Treated with Yava powder 10 gm BD, } \\
\text { twice daily with water for 3 months. }\end{array}$ \\
\hline
\end{tabular}

Sample Size: Sixty Patients (60)

Period of Study: 1 and $1 / 2$ years (18 months)

Individual patient 90 days.

\section{Selection Criteria}

\begin{tabular}{|ll|l|}
\hline \multicolumn{1}{|c|}{ Inclusion Criteria } & \multicolumn{1}{c|}{ Exclusion criteria } \\
\hline 1. & Age between $25-40$ years, both sexes. & 1. Age below 25 years and above 40 years. \\
2. & Patients, willing to take part of study. & 2. Alcohol addiction. \\
3. FBS: $110-125 \mathrm{mg} / \mathrm{dl}$. & 3. Major medical or surgical diseases like CKD, CVD, \\
4. PPBS: $140-199 \mathrm{mg} / \mathrm{dl}$ & CVA, DKA, Hypertensin, Psychiatric problem etc. \\
5. Family history of Type-II DM. & 4. Pregnant and lactating mother. \\
& 5. Not willing to given consent. \\
& 6. Patient on treatment developing side-effects. \\
\hline
\end{tabular}


Laboratory Investigations: FBS, PPBS, Serum Urea, Serum Creatinine.

Diagnostic Criteria

\begin{tabular}{|l|l|}
\hline Subjective Criteria & Objective Criteria \\
\hline 1. Alasya 2. Karapadadaha. 3. Pipasadhikya & 1. FBS. \\
4. Swedatipravritti. 5. Shitapriyata. 6. Madhuramasya. & 2. PPBS. \\
7. Swapnasukha & \\
\hline
\end{tabular}

Assessment Criteria: Subjective Parameters

\begin{tabular}{|l|l|l|}
\hline Subjective Parameters & Findings & Scoring \\
\hline 1. Alasya & None & 0 \\
\cline { 2 - 3 } 2. Karapadadaha & Mild & 1 \\
\cline { 2 - 3 } 3. Pipasadhikya & Moderate & 2 \\
\cline { 2 - 3 } 4. Swedatipravritti & Severe & 3 \\
5. Shitapriyata & & \\
7. Sadhuramasya & & \\
\hline
\end{tabular}

Objective Parameters

\begin{tabular}{|c|l|l|c|}
\hline S.No. & Objective Parameters & Range & Scoring \\
\hline 1. & \multirow{2}{*}{ FBS } & $<110$ & 0 \\
\cline { 3 - 4 } & & $110-115$ & 1 \\
\cline { 3 - 4 } & & $116-120$ & 2 \\
\hline 2. & \multirow{2}{*}{ PPBS } & $121-125$ & 3 \\
\hline & & $<140$ & 0 \\
\hline & & $140-159$ & 1 \\
\cline { 3 - 4 } & & $160-179$ & 2 \\
\hline & & $180-199$ & 3 \\
\hline
\end{tabular}

Assessment of overall effect

\section{Statistical Analysis}

\begin{tabular}{|l|l|l|}
\hline 1. & Complete remission & $100 \%$ relief in sign and symptoms \\
\hline 2. & Marked improvement & $\geq 75 \%$ to $<100 \%$ relief in sign and symptoms \\
\hline 3. & Moderate improvement & $\geq 50 \%$ to $<75 \%$ relief in sign and symptoms \\
\hline 4. & Mild improvement & $\geq 25 \%$ to $<50 \%$ relief in sign and symptoms \\
\hline 5. & Insignificant Improvement & $<25 \%$ relief in sign and symptoms \\
\hline
\end{tabular}

The obtained data were analyzed statistically. The values were expressed as Mean $(\bar{X}) \pm$ SEM (Standard Error of Mean). The data were analyzed by Paired ' $t$ ' test. A level of $p<0.001$ were considered as statistically highly significant and $\mathrm{p}<0.05$ were considered as statistically significant. Level of significance were noted and interpreted accordingly.

\section{OBSERVATIONS AND RESULT}

All the patients of this study were registered in a specialized research format with their informed consent. The clinical trial was conducted and the observation were discussed under the Demographic profile, Clinical profile, Laboratory profile and Therapeutic profile in 60 patients.

\section{Demographic Profile in 60 Patients}

$\checkmark$ Age: Maximum patients were recorded in the age group of 36-40 years (50\%).

$\checkmark$ Sex: Majority of the patients were male (60\%).

$\checkmark$ Marital Status: $83.33 \%$ of the patients who have undergone this study were married.

$\checkmark$ Occupation: Maximum (35\%) were involves in business, 30\% were involves in domestic household chores, $16.67 \%$ were involved in some kind of service, $8.33 \%$ were tailor, $5 \%$ were labors, on daily wages or in factories as well, and $5 \%$ was student.

$\checkmark$ Socio-Economic Status: $58.33 \%$ of the patients were belong to the middle class, while $33.33 \%$ of the patients were in lower class and $8.33 \%$ of the patients was from upper class of the society. 


\section{Clinical Profile in 60 Patients}

$\checkmark$ Dietary Habit: maximum patients (58.33\%) were having Visamasana, followed by $21.67 \%$ Adhyasana, $11.67 \%$ Samasana and rest of the $8.33 \%$ were having the habit of Alpasana.

$\checkmark$ Body Weight: most of the patients (35 Patients) were having normal body weight (58.33\%), 21 patients were having over weight (35\%) and rest of the 4 patients $(6.67 \%)$ were under weight.

$\checkmark$ Dominant Rasa in diet: Analysis on the basis of dominant rasa in the diet showed that maximum patient had inclination for Madhura rasa (51.67\%) followed by Amla rasa (18.33\%), Lavana rasa (13.33\%), Katu rasa (6.67\%), Tikta rasa $(6.67 \%)$, Kasaya rasa $(3.33 \%)$.

$\checkmark$ Sleeping Habit: Table shows that $38.33 \%$ of the patients were having less sleep, 36.67\% were having disturbed sleep and $25 \%$ having normal sleep.

$\checkmark$ Day Sleep: 31 patients (51.67\%) were having daily day sleep, followed by 15 Patients (25\%) were having occasional day sleep and 14 patients $(23.33 \%)$ never had day sleep.

$\checkmark$ Nature of work: 31 patients (51.67\%) had sedentary lifestyle whereas 23 patients (38.33\%) had Active work and 6 patients $(10 \%)$ hav heavy work in their schedule.

$\checkmark$ Sharira Prakriti: Only dwandaja Prakriti were found in this observation, of which $43.33 \%$ were pitta-kapha prakriti, while $33.33 \%$ were vata-kaphaja prakriti and $23.33 \%$ were found to having vata-pitta prakriti.

$\checkmark$ Family History: maximum number of patients i.e. 43 patients (71.67\%) had family history of Prameha and 17 patients $(28.33 \%)$ had no family history of Prameha.

Table 1: Showing Chief complaint of Both Groups

\begin{tabular}{|c|c|c|c|c|c|}
\hline \multirow{2}{*}{ S.No. } & \multirow{2}{*}{ Chief Complaint } & \multicolumn{2}{|c|}{ No. of Patients } & \multirow{2}{*}{ Total } & \multirow{2}{*}{ Percentage } \\
\cline { 3 - 4 } & & Group A & Group B & & \\
\hline 1. & Alasya & 29 & 28 & 57 & $95 \%$ \\
\hline 2. & Kara-pada daha & 20 & 19 & 39 & $65 \%$ \\
\hline 3. & Pipasadhikya & 18 & 17 & 35 & $58.33 \%$ \\
\hline 4. & Swedatipravritti & 24 & 22 & 46 & $76.67 \%$ \\
\hline 5. & Shita priyata & 14 & 16 & 30 & $50 \%$ \\
\hline 6. & Madhuram-asya & 26 & 20 & 46 & $76.67 \%$ \\
\hline 7. & Swapnasukha & 24 & 19 & 43 & $71.67 \%$ \\
\hline
\end{tabular}

Laboratory Profile in 60 Patients

Table 2: Showing FBS of the 60 Patients

\begin{tabular}{|c|c|c|c|c|c|}
\hline \multirow{2}{*}{ S.No. } & \multirow{2}{*}{ FBS } & \multicolumn{2}{|c|}{ No. of Patients } & \multirow{2}{*}{ Total } & \multirow{2}{*}{ Percentage } \\
\cline { 3 - 4 } & & Group A & Group B & & \\
\hline 1. & $110-115 \mathrm{mg} / \mathrm{dl}$ & 06 & 08 & 14 & $23.33 \%$ \\
\hline 2. & $116-120 \mathrm{mg} / \mathrm{dl}$ & 09 & 10 & 19 & $31.67 \%$ \\
\hline 3. & $121-125 \mathrm{mg} / \mathrm{dl}$ & 15 & 12 & 27 & $45 \%$ \\
\hline
\end{tabular}

Table 3: Showing PPBS of the 60 Patients

\begin{tabular}{|c|c|c|c|c|c|}
\hline \multirow{2}{*}{ S.No. } & PPBS & \multicolumn{2}{|c|}{ No. of Patients } & \multirow{2}{*}{ Total } & \multirow{2}{*}{ Percentage } \\
\cline { 3 - 4 } & & Group A & Group B & & \\
\hline 1. & $140-159 \mathrm{mg} / \mathrm{dl}$ & 04 & 07 & 11 & $18.33 \%$ \\
\hline 2. & $160-179 \mathrm{mg} / \mathrm{dl}$ & 10 & 10 & 20 & $33.33 \%$ \\
\hline 3. & $180-199 \mathrm{mg} / \mathrm{dl}$ & 16 & 13 & 29 & $48.33 \%$ \\
\hline
\end{tabular}

Table 4: Showing Serum Urea of the 60 Patients

\begin{tabular}{|c|c|c|c|c|c|}
\hline \multirow{2}{*}{ S.No. } & \multirow{2}{*}{ Serrum Urea } & \multicolumn{2}{|c|}{ No. of Patients } & \multirow{2}{*}{ Total } & \multirow{2}{*}{ Percentage } \\
\cline { 3 - 4 } & & Group A & Group B & & \\
\hline 1. & $10-15 \mathrm{mg} / \mathrm{dl}$ & 10 & 06 & 16 & $26.67 \%$ \\
\hline 2. & $16-20 \mathrm{mg} / \mathrm{dl}$ & 07 & 11 & 18 & $30 \%$ \\
\hline 3. & $21-25 \mathrm{mg} / \mathrm{dl}$ & 10 & 07 & 17 & $28.33 \%$ \\
\hline 4. & $26-30 \mathrm{mg} / \mathrm{dl}$ & 03 & 06 & 09 & $15 \%$ \\
\hline
\end{tabular}


Int. J. Ayur. Pharma Research, 2021;9(Suppl 1):36-43

Table 5: Showing Serrum Creatinine level of the 60 Patients

\begin{tabular}{|c|c|c|c|c|c|}
\hline S.No. & \multirow{2}{*}{$\begin{array}{c}\text { Serrum } \\
\text { Creatinine }\end{array}$} & \multicolumn{2}{|c|}{ No. of Patients } & \multirow{2}{*}{ Total } & \multirow{2}{*}{ Percentage } \\
\cline { 3 - 4 } & & Group A & Group B & & \\
\hline 1. & $0.5-1.5 \mathrm{mg} / \mathrm{dl}$ & 30 & 30 & 60 & $100 \%$ \\
\hline 2. & $>1.5 \mathrm{mg} / \mathrm{dl}$ & 00 & 00 & 00 & $0 \%$ \\
\hline
\end{tabular}

Table 6: Showing LFT of the 60 Patients

\begin{tabular}{|c|l|l|l|l|}
\hline \multirow{2}{*}{ S.No. } & \multicolumn{1}{|c|}{ LFT } & \multicolumn{2}{|l|}{ No. of Patients } & \multirow{2}{*}{ Normal Range } \\
\cline { 3 - 4 } & & Group A (Mean) & Group B (Mean) & \\
\hline 1. & Billirubin (mg/dl) & 0.50 & 0.48 & $0.2-1.2 \mathrm{mg} / \mathrm{dl}$ \\
\hline 2. & SGOT/AST (IU/L) & 23.70 & 21.93 & $8-54 \mathrm{IU} / \mathrm{L}$ \\
\hline 3. & SGPT/ALT (IU/L) & 28.07 & 31.13 & $7-56 \mathrm{IU} / \mathrm{L}$ \\
\hline 4. & ALP (IU/L) & 68.10 & 66.70 & $44-147 \mathrm{IU} / \mathrm{L}$ \\
\hline
\end{tabular}

Observation on Therapeutic Trial:

$\mathrm{n}=$ Number of Patients, BT $=$ Before Treatment, $\mathrm{AT}=$ After Treatment, $\mathrm{MD}=$ Difference in Mean, $\mathrm{SD}=\mathrm{Standard}$ Deviation, $\mathrm{SE}=$ Standard Error, ' $\mathrm{t}$ '= Paired t test, ' $\mathrm{p}$ '= Level of Significance

Table 7: Effect of Trial Drug on Subjective Parameters of Group A Patients

\begin{tabular}{|c|c|c|c|c|c|c|c|c|c|}
\hline \multirow{2}{*}{$\begin{array}{l}\text { Subjective } \\
\text { Parameters }\end{array}$} & \multirow[t]{2}{*}{$\mathrm{n}$} & \multicolumn{2}{|c|}{ Mean Score } & \multirow[t]{2}{*}{ MD } & \multirow{2}{*}{$\begin{array}{c}\text { \% of } \\
\text { Relief }\end{array}$} & \multirow{2}{*}{$\begin{array}{l}\text { SD } \\
( \pm)\end{array}$} & \multirow{2}{*}{$\begin{array}{l}\text { SE } \\
( \pm)\end{array}$} & \multirow{2}{*}{$\begin{array}{c}\text { 't' } \\
\text { Value }\end{array}$} & \multirow{2}{*}{$\begin{array}{c}\text { 'p' } \\
\text { Value }\end{array}$} \\
\hline & & BT & AT & & & & & & \\
\hline Alasya & 29 & 1.931 & 0.724 & 1.207 & $62.50 \%$ & 1.346 & 0.250 & 4.83 & $<0.001$ \\
\hline Karapada daha & 20 & 1.8 & 0.65 & 1.15 & $63.89 \%$ & 1.089 & 0.244 & 4.71 & $<0.001$ \\
\hline PipasaAdhikya & 18 & 2.056 & 0.889 & 1.167 & $56.76 \%$ & 1.098 & 0.259 & 4.51 & $<0.001$ \\
\hline Swedatipravritti & 24 & 1.917 & 0.75 & 1.167 & $60.88 \%$ & 1.239 & 0.253 & 4.61 & $<0.001$ \\
\hline Shitapriyata & 14 & 1.429 & 0.714 & 0.715 & $50.03 \%$ & 0.611 & 0.163 & 4.39 & $<0.001$ \\
\hline Madhuramasya & 26 & 1.769 & 0.846 & 0.923 & $52.18 \%$ & 0.977 & 0.192 & 4.80 & $<0.001$ \\
\hline Swapnasukha & 24 & 1.625 & 0.708 & 0.917 & $56.43 \%$ & 0.974 & 0.199 & 4.60 & $<0.001$ \\
\hline
\end{tabular}

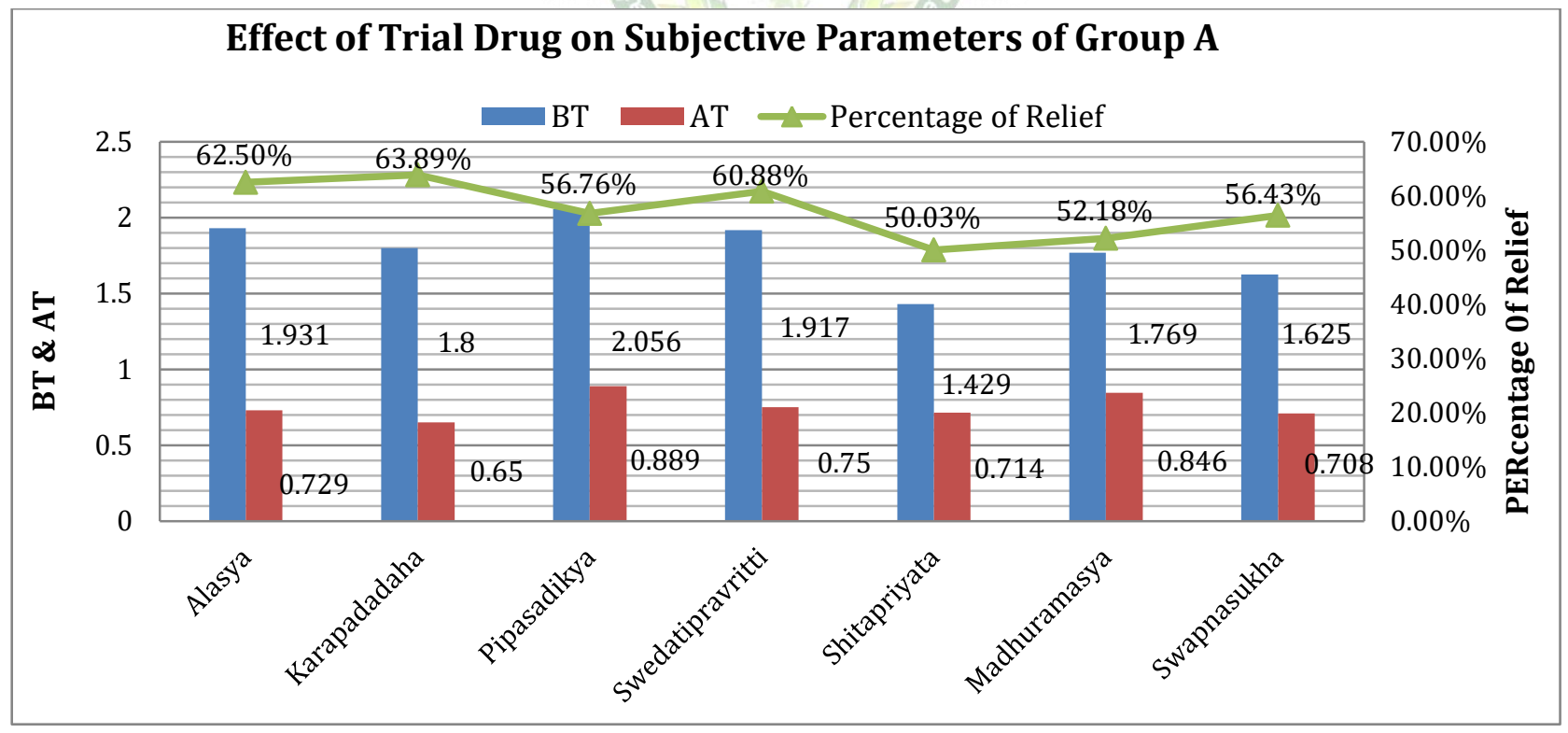

Graph 1: Effect of Trial Drug on Subjective Parameters of Group A

Table 8: Effect of Trial Drug on Objective Parameters of Group A Patients

\begin{tabular}{|l|c|c|c|c|c|c|c|c|c|}
\hline $\begin{array}{l}\text { Objective } \\
\text { Parameters }\end{array}$ & \multirow{2}{*}{$\mathbf{n}$} & \multicolumn{2}{|c|}{ Mean Score } & \multirow{2}{*}{ MD } & $\begin{array}{c}\text { \% of } \\
\text { Relief }\end{array}$ & $\begin{array}{c}\text { SD } \\
\mathbf{( \pm )}\end{array}$ & $\begin{array}{c}\text { SE } \\
(\mathbf{\pm})\end{array}$ & $\begin{array}{c}\text { 't' } \\
\text { Value }\end{array}$ & $\begin{array}{c}\text { 'p' } \\
\text { Value }\end{array}$ \\
\cline { 3 - 9 } & $\mathbf{B T}$ & $\mathbf{A T}$ & & 1.6 & $65.58 \%$ & 1.404 & 0.256 & 6.25 & $<0.001$ \\
\hline FBS & 30 & 0.233 & 0.733 & 1.7 & $70.83 \%$ & 1.393 & 0.254 & 6.68 & $<0.001$ \\
\hline PPBS & 30 & 2.4 & 0.7 & 1.7 &
\end{tabular}




\section{Effect of Trial Drug on Objective Parameters of Group A}

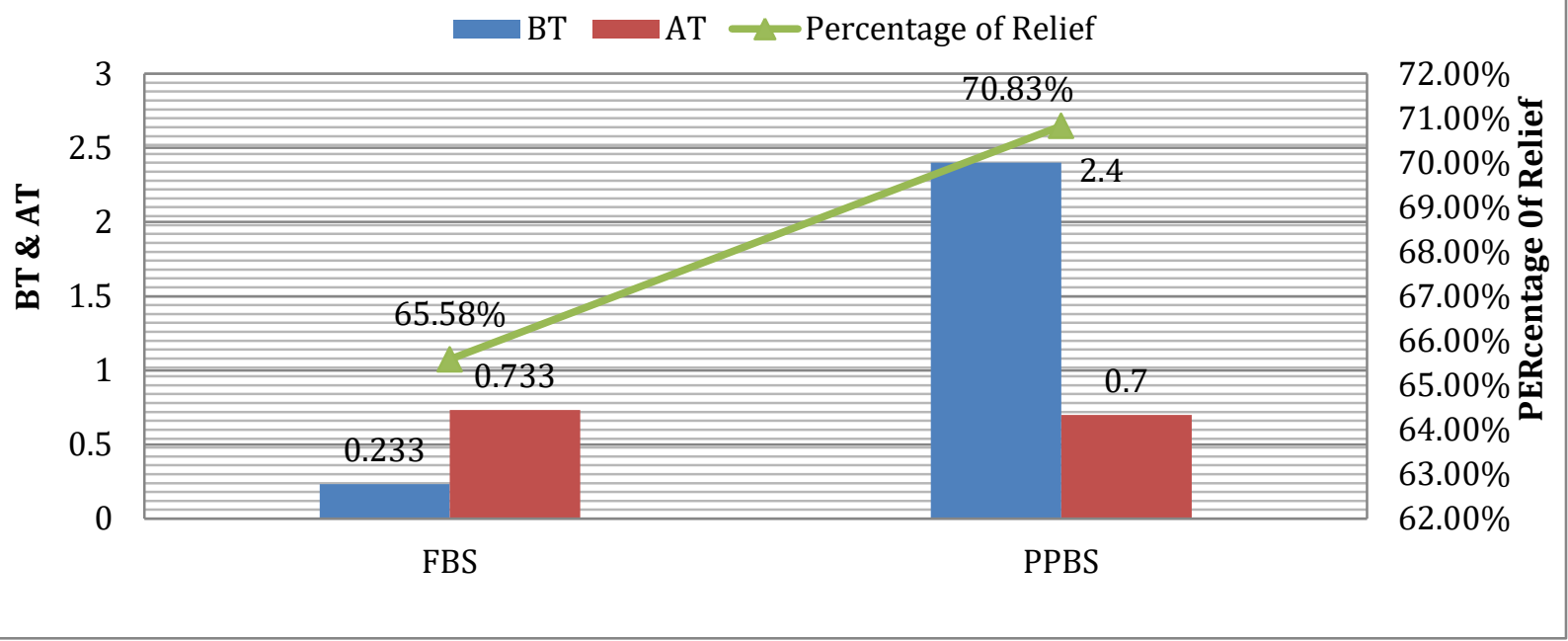

Graph 2: Effect of Trial Drug on Objective Parameters of Group A

Table 9: Effect of Trial Drug on Subjective Parameters of Group B Patients

\begin{tabular}{|c|c|c|c|c|c|c|c|c|c|}
\hline \multirow{2}{*}{$\begin{array}{l}\text { Subjective } \\
\text { Parameters }\end{array}$} & \multirow[t]{2}{*}{$\mathbf{n}$} & \multicolumn{2}{|c|}{ Mean Score } & \multirow[t]{2}{*}{ MD } & \multirow{2}{*}{$\begin{array}{l}\% \text { of } \\
\text { Relief }\end{array}$} & \multirow{2}{*}{$\begin{array}{l}\text { SD } \\
( \pm)\end{array}$} & \multirow{2}{*}{$\begin{array}{l}\text { SE } \\
( \pm)\end{array}$} & \multirow{2}{*}{$\begin{array}{c}\text { 't' } \\
\text { Value }\end{array}$} & \multirow{2}{*}{$\begin{array}{c}\text { 'p' } \\
\text { Value }\end{array}$} \\
\hline & & BT & AT & & & & & & \\
\hline Alasya & 29 & 1.786 & 0.929 & 0.857 & $48 \%$ & 1.145 & 0.217 & 3.95 & $<0.001$ \\
\hline Karapada daha & 19 & 1.474 & 0.842 & 0.632 & $42.88 \%$ & 0.761 & 0.175 & 3.62 & $<0.01$ \\
\hline PipasaAdhikya & 17 & 1.706 & 1 & 0.706 & $41.38 \%$ & 0.849 & 0.206 & 3.43 & $<0.01$ \\
\hline Swedatipravritti & 22 & 2.136 & 1.182 & 0.955 & $44.70 \%$ & 1.09 & 0.232 & 4.1 & $<0.001$ \\
\hline Shitapriyata & 16 & 1.688 & $1 \%$ & 0.688 & $40.76 \%$ & 0.704 & 0.176 & 3.9 & $<0.01$ \\
\hline Madhuramasya & 20 & 1.85 & 1.1 & 0.75 & $40.54 \%$ & 0.911 & 0.204 & 3.68 & $<0.01$ \\
\hline Swapnasukha & 19 & 1.737 & 0.947 & 0.79 & $45.45 \%$ & 0.918 & 0.211 & 3.74 & $<0.01$ \\
\hline
\end{tabular}

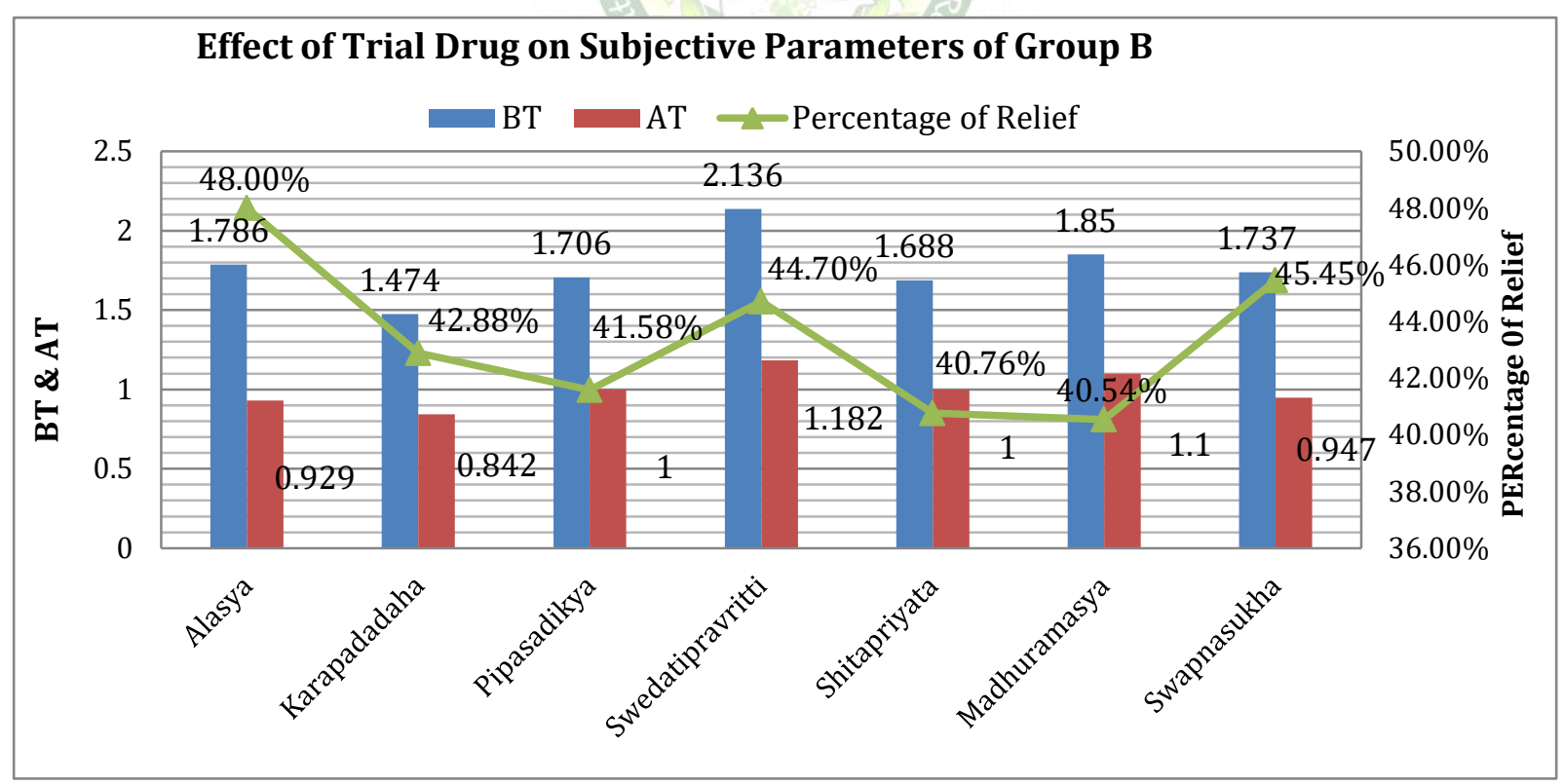

Graph 3: Effect of Trial Drug on Subjective Parameters of Group B

Table 10: Effect of Trial Drug on Objective Parameters of Group B Patients

\begin{tabular}{|c|c|c|c|c|c|c|c|c|c|}
\hline \multirow{2}{*}{$\begin{array}{l}\text { Objective } \\
\text { Parameters }\end{array}$} & \multirow[t]{2}{*}{$\mathbf{n}$} & \multicolumn{2}{|c|}{ Mean Score } & \multirow[t]{2}{*}{ MD } & \multirow{2}{*}{$\begin{array}{c}\text { \% of } \\
\text { Relief }\end{array}$} & \multirow{2}{*}{$\begin{array}{l}\text { SD } \\
( \pm)\end{array}$} & \multirow{2}{*}{$\begin{array}{l}\text { SE } \\
( \pm)\end{array}$} & \multirow{2}{*}{$\begin{array}{c}\text { 't' } \\
\text { Value }\end{array}$} & \multirow{2}{*}{$\begin{array}{c}\text { 'p' } \\
\text { Value }\end{array}$} \\
\hline & & BT & AT & & & & & & \\
\hline BS & 30 & 2.133 & 0.833 & 1.3 & $60.95 \%$ & 1.442 & 0.263 & 4.94 & $<0.001$ \\
\hline PPBS & 30 & 2.2 & 0.967 & 1.233 & $56.06 \%$ & 1.135 & 0.207 & 5.95 & $<0.001$ \\
\hline
\end{tabular}




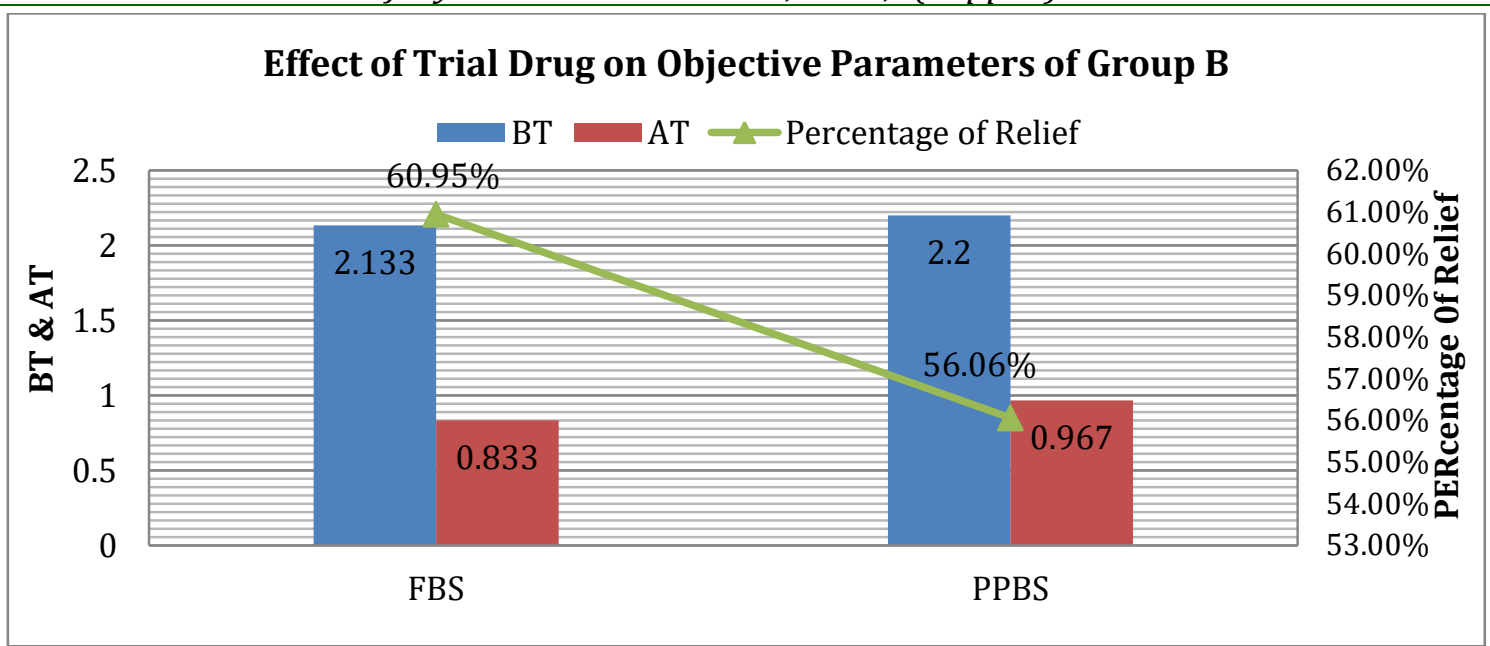

Graph 4: Effect of Trial Drug on Objective Parameters of Group B

Table 10: Showing overall effect of treatment in 60 patients

\begin{tabular}{|l|c|c|c|c|c|c|}
\hline \multirow{2}{*}{ Overall Effect } & \multicolumn{2}{|c|}{ Group A (30 Patients) } & \multicolumn{2}{c|}{ Group B (30 Patients) } & \multicolumn{2}{c|}{ Total (60 Patients) } \\
\cline { 2 - 7 } & No. of Pts. & \% of Pts. & No. of Pts. & \% of Pts. & No. of Pts. & \% of Pts. \\
\hline $\begin{array}{l}\text { Complete Remission } \\
(100 \% \text { Relief })\end{array}$ & 0 & $0 \%$ & 0 & $0 \%$ & 0 & $0 \%$ \\
\hline $\begin{array}{l}\text { Marked Improvement } \\
(\geq 75 \% \text { to }<100 \% \text { relief })\end{array}$ & 09 & $30 \%$ & 05 & $16.67 \%$ & 14 & $23.33 \%$ \\
\hline $\begin{array}{l}\text { Moderate Improvement } \\
(\geq 50 \% \text { to <75\% relief) }\end{array}$ & 12 & $40 \%$ & 07 & $23.33 \%$ & 19 & $31.67 \%$ \\
\hline $\begin{array}{l}\text { Mild Improvement } \\
\text { ( } \geq 25 \% \text { to <50\% relief) }\end{array}$ & 09 & $30 \%$ & 14 & $46.67 \%$ & 23 & $38.33 \%$ \\
\hline $\begin{array}{l}\text { Insignificant Result } \\
(<25 \% \text { relief) }\end{array}$ & 00 & $00 \%$ & 04 & $13.33 \%$ & 04 & $6.67 \%$ \\
\hline
\end{tabular}

\section{Overall assessment}

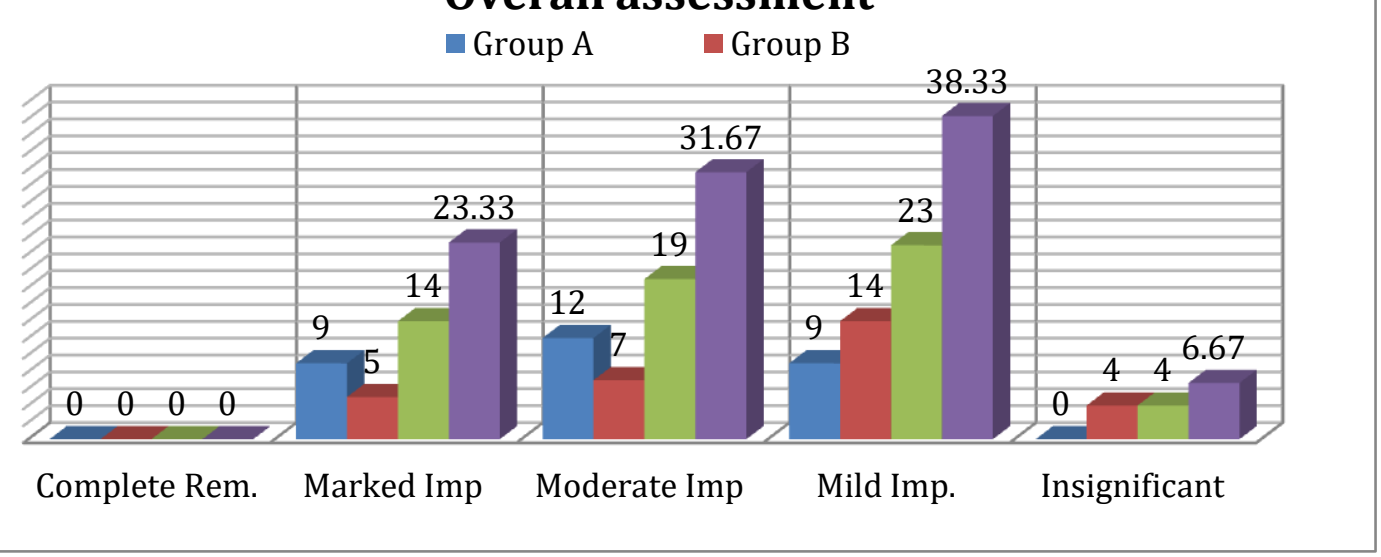

\section{Graph 5: Showing overall effect of treatment in 60 patients}

\section{DISCUSSION}

For all clinical study, coherent interpretation and productive discussion is important, so that it contributes at least "squirrel service" to the remedial field, in turn serving the humanity. Here an attempt is made to discuss the concepts with respect to literary as well as on clinical work. The rapid increase in population, high ethnic susceptibility, rapid urbanization, the modern lifestyle with too much rich and refined food, too little exercise and stress most likely triggerd a Diabetes epidemic. The most disturbing trend in the shift in age of onset of prediabetes is to younger age in the recent years. This will have long lasting adverse effect on the nation's health and economy.

Beside the laboratory investigations an imaginary scoring protocol have been done for subjective and objective parameters, and scored by the condition nil (0), mild (1), moderate (2) and severe (3). The scoring points of BT and AT has been analyzed mathematically and statistically. The overall responses have been assessed by 5 categories, where insignificant response claimed by $<25 \%$ relief, mild improvement claimed by $\geq 25 \%$ to $<50 \%$ relief, moderate improvement claimed by $\geq 50 \%$ to $<75 \%$ 
relief, marked improvement claimed by $\geq 75 \%$ to < $100 \%$ relief and complete remission claimed by $100 \%$ relief.

In Group A, 30\% of the patients achieved marked improvement, $40 \%$ of the patients achieved moderate improvement, and $30 \%$ of the patients achieved mild improvement. In Group B, $16.67 \%$ of the patients achieved marked improvement, $23.33 \%$ of the patients achieved moderate improvement, $46.67 \%$ of the patients achieved mild improvement and 13.33\% having insignificant result. In summing up, it can be said that the present study showed significant remission in signs and symptoms of Prameha vis-à-vis Prediabetes corroborated with definite reduction in blood sugar levels. Therefore it is imperative that Powder Kuberaksha and Powder Yava helps in successful management of the disease and the drug Kuberaksha showed more significant result than the drug Yava.

\section{CONCLUSION}

In this study the broad term Prameha is correlated with Prediabetes and Madhumeha is correlated with Diabetes with its complications. Prediabetes is a condition where blood glucose level is higher than normal but not high enough to diagnosed as Diabetes. The chief complaints in this study are present in Poorvarupa of Prameha. These symptoms are almost same with the recently correlated prediabetes. Sedentary lifestyle, increased stress and strain, food habit, family history etc. are the main factors for the causation of Prediabetes. Pathya is the foundation stone for the treatment of prediabetes.

In Alasya, Swedatipravritti both drugs showed highly significant result where $\mathrm{p}<0.001$ but the percentage of relief was more in case of Kuberaksha. In Karapadadaha, Pipasadhikya, Shitapriyata, Madhuramasya and Swapnasukha the drug showed highly significant result $(\mathrm{p}<0.001)$ and the drug Yava also showed significant results $(\mathrm{p}<0.01)$. Percentage of relief was more in Group A. In case of FBS and PPBS both drugs showed highly significant result i.e., $\mathrm{p}<0.001$ and the percentage of relief was more in Group A (Kuberaksha). The study confirms that Kuberaksha and Yava are effective and safe in the treatment of prediabetes and definitely reduces the symptoms including FBS and PPBS. Treatment through Kuberaksha (Caesalpinia bonduc) was more effecting in combating prediabetes as compared to Yava (Hordeum vulgare). No adverse effects were observed during treatment. The present clinical study (Research work) may through a new light to the field in the management of Prediabetes and prevention of Madhumeha (Diabetes and its complication).

\section{REFERENCES}

1. Yadavji Trikamji Acharya, Dalhan Nibandha Sangraha Commentary on Sushruta Samhita, $6^{\text {th }}$ edition, Chowkhamba Sanskrit Pratisthan, Varanasi, Sutrasthan, chap 23/4, p.144.

2. Cakrapani Dutta, Ayurved Deepika Commentary on Caraka Samhita of Agnivesa, edited by Yadavji Trikamji Acharya, Sutrasthan, Chap 25/40, Chowkhamba Orientalia, Varanasi, 2009, p.132.

3. The 10 leading causes of death in World in 2000 and 2012", World Health Organization, available on the official website www.who.int.

4. Diabetes fact file, World Health Organization, official website www.who.int.

5. Kumar A, Goel NK, Jain RB, Khanna P, India towards diabetes control: key issue, Australas Med J.2013; 6(10): 524-531.

6. Maji D; Prevention of microvascular and macrovascular complication in Diabetes Mellitus, Journal at Indian Medical Association, Vol 102, no08, August 2004, Kolkata, p.2426-236.

7. Kasper, Fauci, Hauser, Longo, Jameson, Loscalzo, Harrison's principles of Internal Medicine, Vol II, Mc Graw- Hill Education, 18 ${ }^{\text {th }}$ edition, p.2968.

8. American Diabetes Association (Jan 2017), Classification and diagnosis of Diabetes, Diabetes care. 40 (suppl); S11-S24.

9. ADA diagnosis and classification of DM. Diabetes care. 2011 Jan; 34 (suppl 1): S62-9. Available on http://dx.doi.org/10.2337/dc11-S062.

10. Whiting Dr. Guariguata L, IDF Diabetes atlas; Global estimates of the prevalence of diabetes for 2011 \& 2030. Diabetes Res Clinpract, 2011, 94: 311-321: Journal.

\section{Cite this article as}

Trisha Talapatra, Sukumar Ghosh, Rina Ghosh, Shailendra Kumar Singh. A Comparative Clinical Evaluation on the Efficacy of Kuberaksha \& Yava with Lifestyle Modification, in the Management of Prameha with Special Reference to Prediabetes. International Journal of Ayurveda and Pharma Research. 2021;9(Suppl 1):36-43. https://doi.org/10.47070/ijapr.v9iSuppl1.2110

Source of support: Nil, Conflict of interest: None Declared

*Address for correspondence
Dr. Trisha Talapatra
P.G Scholar,
Department of Kayachikitsa,
Institute of Post Graduate Ayurvedic
Education \& Research at S.V.S.P, 294,
3/1, A.P.C Road, Kol-09, West Bengal,
India.
Email: trishatalapatra4@gmail.com
Contact: 7003467069

*Address for correspondence Dr. Trisha Talapatra

P.G Scholar

Department of Kayachikitsa,

Institute of Post Graduate Ayurvedic

Education \& Research at S.V.S.P, 294,

India.

Contact: 7003467069

Disclaimer: IJAPR is solely owned by Mahadev Publications - dedicated to publish quality research, while every effort has been taken to verify the accuracy of the content published in our Journal. IJAPR cannot accept any responsibility or liability for the articles content which are published. The views expressed in articles by our contributing authors are not necessarily those of IJAPR editor or editorial board members. 